\title{
EOSINOPHILIC INFLAMMATION IN ALLERGIC RHINITIS AND NASAL POLYPOSIS
}

\author{
Aleksandar PERIĆ ${ }^{1}$, Danilo VOJVODIĆ², Biserka VUKOMANOVIĆ-ĐURĐEVIĆ , \\ and Nenad BALETIĆ ${ }^{1}$ \\ Department of Otorhinolaryngology ${ }^{1}$, Institute of Medical Research, Division of Clinical and Experimental \\ Immunology ${ }^{2}$, Institute of Pathology ${ }^{3}$, Military Medical Academy, Belgrade, Serbia \\ Received in June 2011 \\ CrossChecked in September 2011 \\ Accepted in November 2011
}

\begin{abstract}
On histopathological examination, nasal polyps and nasal mucosa in allergic rhinitis show different forms of pseudostratified respiratory epithelium, whereas the dominant characteristic of lamina propria is an eosinophilic infiltration. The aim of this study was to compare interleukin (IL)-5 and eosinophilic cationic protein (ECP) levels in the nasal fluid of 42 patients: 12 with allergic rhinitis and nasal septal deviation, 17 non-atopic patients with nasal polyposis, and 13 atopic nasal polyp patients were enrolled in this crosssectional study. Nasal secretion samples were collected a few days before surgery. The levels of IL-5 were measured using flow cytometry and the ECP using a commercial ELISA kit. In addition, we counted eosinophils in hematoxylin-and-eosin-stained sections of all nasal polyp and all nasal mucosa samples taken from the inferior nasal turbinates during septoplasty. A significantly higher concentration of IL-5 was found in the nasal fluid of atopic patients with nasal polyposis than in non-atopic nasal polyp patients $(\mathrm{p}=0.025)$ and patients with allergic rhinitis $(\mathrm{p}=0.05)$. ECP was higher in atopic nasal polyp patients than in patients with allergic rhinitis $(p<0.0001)$ and than in non-atopic nasal polyp patients $(\mathrm{p}<0.0001)$. Polyp eosinophils were higher in atopic' than in non-atopic patients $(\mathrm{p}<0.0001)$ and higher than in the mucosa of patients with allergic rhinitis $(\mathrm{p}<0.0001)$. These however had significantly more mucosal eosinophils than was found in the polyps of non-atopic patients' $(p=0.025)$. ECP levels in nasal fluid and eosinophil counts in tissue specimens correlated well in all three groups of patients. Our study has shown that atopic nasal polyp patients have a higher level of eosinophilic inflammation than non-atopic patients with nasal polyps and patients with allergic rhinitis.
\end{abstract}

KEY WORDS: eosinophilic cationic protein, eosinophils, epithelium, interleukin-5, nasal fluid

Allergic rhinitis is the most common atopic disease in the human population as it affects one in four people worldwide $(1,2)$. Its prevalence in the European countries ranges between $15 \%$ and $25 \%$, with a tendency to rise by about $3.5 \%$ with every decade (3). It is a type I allergic reaction mediated by mast cellbound immunoglobulin $\mathrm{E}$ (IgE) with a typical helper T-cell type 2 (Th2) profile (3).

Nasal polyposis is characterised by the proliferation of pseudostratified respiratory epithelium, thickening of the basement membrane, oedema, proliferation of fibroblasts, focal fibrosis, and inflammatory infiltration of the lamina propria (4). The stromal layer of the polyp tissue includes mixed inflammatory cells. The predominant histological form of nasal polyposis is the eosinophilic type, with an incidence of about $90 \%$ (5). The non-eosinophilic form of nasal polyps is much less common and the dominant cells in the stroma are lymphocytes and plasmocytes (5). Polyps usually originate from the anterior ethmoid sinus and descend into the nasal cavity through the middle meatus, causing symptoms such as nasal obstruction, anosmia, 
sneezing, rhinorrhoea, and itching (4). The aetiology of nasal polyposis is not well known, but may involve several potential factors such as chronic persistent inflammation and oxidative stress. Inflammation triggers include bacterial, fungal and viral infection, allergy, and environmental pollution $(6,7)$.

Ramanathan et al. (8) suggest that increased presence of eosinophils is associated with ineffective local T helper (Th) 1-based immune response (8). Weakened Th1 response in nasal polyp patients may follow the down-regulation of specific toll-like receptors (TLR) involved in immune response. Nasal polyposis, which affects about $2.7 \%$ of the European adult population, usually manifests itself after the age of 20 years (7).

Nasal secretion is the first line of nasal mucosa defence (9). It contains small amounts of cytokines and other inflammatory mediators, produced by epithelial and immunocompetent cells. These peptides are involved in the regulation of inflammation and immune defence.

Tissue eosinophilia is the general characteristic of allergic rhinitis and of $80 \%$ to $90 \%$ of nasal polyps. Activated eosinophils produce and secrete different vasoactive substances, cytokines, chemotactic factors, leukotrienes, major basic proteins, eosinophilic cationic protein (ECP), and eosinophilic peroxidases (EPOs). Kramer et al. (3) suggest thatECP concentration reflects eosinophil count and the degree of inflammation.

Interleukin (IL)-5 is a Th2 cytokine that strongly affects the differentiation, proliferation, chemotactic properties, recruitment into the tissue, and survival of eosinophils $(3,4)$.

The aims of this cross-sectional study were: (a) to compare the IL- 5 and ECP levels detected in nasal fluid of patients with allergic rhinitis, non-atopic, and atopic patients with nasal polyposis; (b) to compare the eosinophil counts in the nasal mucosa of patients with allergic rhinitis, nasal polyp tissue of non-allergic, and in nasal polyp tissue of allergic patients; and (c) to see if there is any correlation between the inflammatory mediator levels in nasal secretions and eosinophil count in the inflamed tissues.

\section{METHODS}

\section{Patients}

The study included forty-two ( $\mathrm{n}=42$ ) patients, 12 with allergic rhinitis and septal deviation, 17 non- atopic patients and 13 atopic patients with bilateral nasal polyposis and indications for surgical treatment. All procedures were performed according to the Helsinki Declaration. All patients gave their written informed consent for participating in the study. The study was approved by the Research Ethics Committee of the Military Medical Academy, Belgrade, Serbia. The diagnosis of bilateral nasal polyposis was based on documented medical history and on the results of anterior rhinoscopy, nasal endoscopy, and computed tomography (CT), according to the current European Guidelines (10).

The diagnosis of allergic rhinitis followed the guidelines provided by the Allergic Rhinitis and its Impact on Asthma (ARIA) initiative $(1,11)$. It was based on the rhinoscopic/endoscopic findings, on the positive skin-prick test to commonly inhaled allergens, on the presence of symptoms including sneezing, nasal itching, nasal congestion/obstruction, rhinorrhoea, and/or red and tearing eyes for the last a month (1, 11).

The exclusion criteria were: antrochoanal polyps, bronchial asthma, aspirin sensitivity, cystic fibrosis, history of acute respiratory tract infection or treatment with oral and topical corticosteroids, antibiotics and antihistamines for at least three weeks before enrolment, smoking, systemic illness and nasal/sinus surgery for at least six months before the start of the study.

\section{Allergy determination}

The exact atopic status was evaluated in all nasal polyp and rhinitis patients on the basis of clinical criteria, medical history of allergy, positive skin-prick test, and positive serological test. Skin-prick tests were performed on the volar part of the forearm with a standard battery of common aeroallergens (Soluprick, Multi test, Alk-Abello, Denmark) including birch, timothy, mugwort (Artemisia vulgaris), dog, cat, horse, mite (Dermatophagoides farinae, Dermatophagoides pteronyssinus), moulds (Alternaria alternata, Aspergillus fumigatus, Cladosporium herbarum), olive tree, spreading pellitory (Parietaria judaica), ribwort plantain (Plantago lanceolata), and London planetree (Platanus acerifolia). Skin-prick testing also included negative $(0.9 \%$ natriumchloridum solution) and positive $\left(1 \mathrm{mg} \mathrm{mL}^{-1}\right.$ histamine dihydrochloride solution) controls. Reactions were read after $15 \mathrm{~min}$, as follows (12): 0 - negative, erythema only or no reaction; + - wheal $<3 \mathrm{~mm}$; ++ - wheal 3 to $5 \mathrm{~mm}$ with flare; +++ - wheal $>5 \mathrm{~mm}$ to 
$7 \mathrm{~mm}$ with flare; ++++ - wheal $>7 \mathrm{~mm}$ usually with pseudopods and flare. Allergy was diagnosed in patients with a wheal diameter at least $3 \mathrm{~mm}$ larger than that of the negative control, regardless of the allergen.

Total serum IgE level was measured using the ELISA kit (Elitech Diagnostics, Salon-de-Provence, France) and an ELISA reader (Spectra III, Austria). Venous blood was collected and centrifuged, and the serum stored at $-70{ }^{\circ} \mathrm{C}$ until testing. Total serum IgE levels $\geq 160 \mathrm{IU} \mathrm{mL}^{-1}$ were considered abnormal (13).

\section{Sampling of nasal secretions and determination of IL-5 and ECP}

Nasal fluid samples were collected from the nasal cavities of all 42 subjects using a modified absorption method (14-16) a few days before surgery. As baseline nasal secretion can be scarce in healthy subjects, control samples were not taken. All cotton-wool sticks with samples were placed in a $2 \mathrm{~mL}$ Eppendorf tube containing $1 \mathrm{~mL}$ of transfer medium (phosphatebuffered saline with gentamycin $50 \mu \mathrm{g} \mathrm{mL}^{-1}$, penicillin $\mathrm{G} 340 \mathrm{U} \mathrm{mL}^{-1}$, and fungizone $500 \mu \mathrm{g} \mathrm{mL}-1$ ) for $30 \mathrm{~min}$ to allow for mediators to diffuse into the medium, and were then stored at $4{ }^{\circ} \mathrm{C}$ for a maximum of $2 \mathrm{~h}$. Nasal secretion samples were centrifuged at $1000 \mathrm{xg}$ for 10 minutes to separate cellular components. After that, supernatants were stored at $-70{ }^{\circ} \mathrm{C}$ until mediator determination. The concentrations of proinflammatory Th2 cytokine IL- 5 were determined in each of the 42 samples using a commercial flow cytometric kit (Flow Cytomix, Bender MedSystems, USA) on the cytofluorimeter (Beckman Coulter XL-MCL, USA) according to the manufacturer's instructions. The sensitivity of IL-5 detection was $30 \mathrm{pg} \mathrm{mL}^{-1}$. The amount of ECP in the nasal fluid was measured by fluoroimmunoassay (FEIA, UniCAPTM100, Pharmacia Diagnostics AB, Uppsala, Sweden), whose detection limit was $2 \mu \mathrm{g} \mathrm{\textrm {L } ^ { - 1 }}$.

\section{Tissue preparation and quantification of eosinophils}

All the patients were operated on by the same surgeon under general anaesthesia. In the allergic rhinitis group, nasal mucosa samples were taken from the inferior turbinates from patients undergoing septoplasty. Nasal polyps located in the middle meatus were surgically removed. For histological examination, nasal mucosa/polyp samples were fixed in $10 \%$ formaldehyde, embedded in paraffin, cut with the microtome into $5-\mu \mathrm{m}$ sections, and stained with haematoxylin and eosin. Histological examination was performed using a digital optical microscope (Nikon Coolscope, Japan) and a computerised picture analysis system. This system was programmed by Image $\mathbf{J}$ (Java-based image processing program), as described elsewhere (17). Once the glass slide was set, brightfield images could be viewed on the monitor. The visual field was oriented along the whole length of the epithelium basement membrane. Eosinophils were counted in the surface layer of the mucosa at $x 400$ magnification. The surface layer included the pseudostratified respiratory epithelium up to $0.20 \mathrm{~mm}$ below the basal membrane. The rest of the tissue was considered the stromal layer. To yield the mean number of eosinophils per high power field (HPF), 10 randomly chosen HPFs of a single section were examined. We counted the eosinophils in the surface layer in each section and calculated the average number of eosinophils per HPF.

\section{Statistical analysis}

Data are expressed as means \pm standard deviation $( \pm \mathrm{SD})$. A one-way analysis of variance (ANOVA) was used to calculate the differences between the three groups of patients. We used a post-hoc DunnBonferroni correction to assess the level of statistical difference. A p value of 0.05 and less was considered statistically significant. Correlations between IL-5/ ECP levels in nasal secretions and eosinophil counts in the nasal polyp/nasal mucosa tissue were evaluated using the Pearson's correlation test. For all statistical analysis we used the Stat Plus 2007 programme.

\section{RESULTS}

Table 1 shows patient group profiles and skin-prick and total serum IgE findings. All patients with allergic rhinitis and atopic nasal polyposis were positive to the skin-prick test and had increased serum IgE.

Table 2 shows mediator levels in nasal secretion. The mean IL-5 level was significantly higher in atopic patients with nasal polyposis than in non-atopic patients and in patients with allergic rhinitis.

The mean level of ECP was significantly higher in atopic nasal polyposis patients than in non-atopic patients and patients with allergic rhinitis.

Similarly, eosinophil count in atopic patients was significantly higher than in non-atopic patients (55.92 \pm 5.82 vs. $11.12 \pm 2.03, \mathrm{p}<0.0001)$ and patients 
Table 1 Patient group profile

\begin{tabular}{lccc}
\hline & Atopic nasal polyposis & Non-atopic nasal polyposis & Allergic rhinitis \\
\hline Patients & 13 & 17 & 12 \\
\hline Age* / years & $43.85 \pm 14.37$ & $45.24 \pm 14.78$ & $41.47 \pm 12.86$ \\
\hline Men/Women & $8 / 5$ & $13 / 4$ & $9 / 3$ \\
\hline Positive skin prick test & $100 \%(13 / 13)$ & $0 \%(0 / 17)$ & $100 \%(12 / 12)$ \\
\hline Total serum IgE*/ IU mL mL $^{-1}$ & $328.93 \pm 46.25$ & $68.71 \pm 31,84$ & $227.73 \pm 48.92$ \\
\hline
\end{tabular}

*mean \pm standard deviation

Table 2 Mediator levels in nasal secretions

\begin{tabular}{lccc}
\hline & Allergic rhinitis & Non-atopic nasal polyposis & Atopic nasal polyposis \\
\hline $\mathrm{IL}^{*} 5^{*} / \mathrm{pg} \mathrm{mL}^{-1}$ & $216.00 \pm 275.55^{\mathrm{a}}$ & $204.35 \pm 285.97^{\mathrm{b}}$ & $761.38 \pm 885.32$ \\
\hline $\mathrm{ECP}^{*} / \mu \mathrm{g} \mathrm{mL}^{-1}$ & $13.67 \pm 8.87^{\mathrm{c}}$ & $9.00 \pm 4.32^{\mathrm{d}}$ & $60.08 \pm 20.69$ \\
\hline
\end{tabular}

*mean \pm standard deviation

a difference from atopic nasal polyposis $p=0.05$

${ }^{b}$ difference from atopic nasal polyposis $p=0.025$

$c, d$ difference from atopic nasal polyposis $p<0.0001$

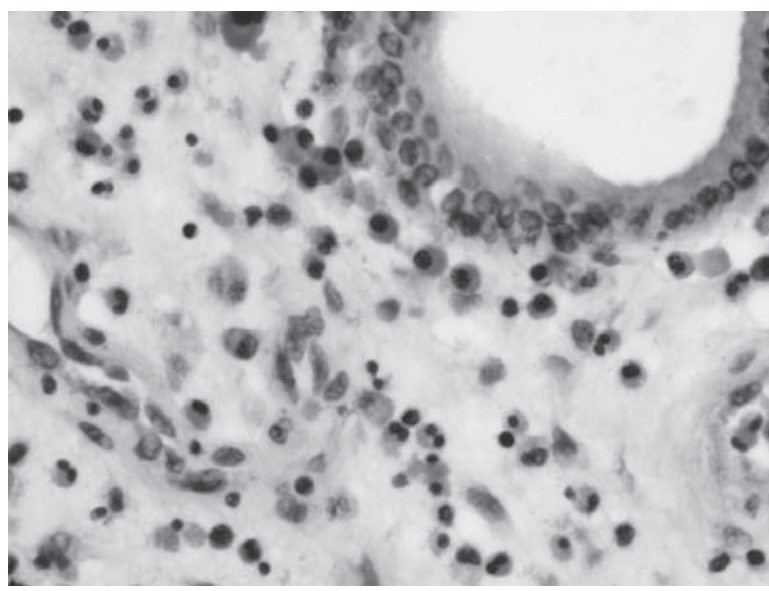

Figure 1 Eosinophils in the surface layer of tunica mucosa with many seromucous glands in patients with allergic rhinitis (haematoxylin and eosin stain, magnification 400x).

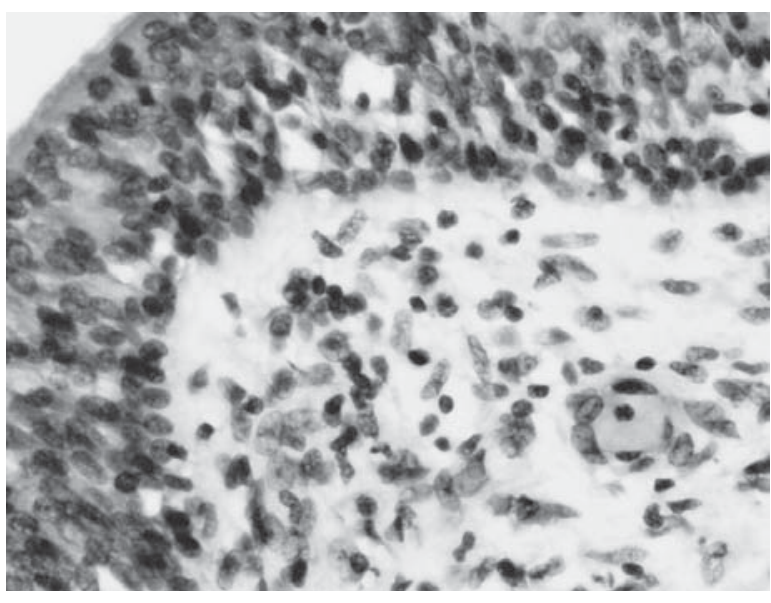

Figure 3 Weak eosinophil infiltration in the nasal polyp epithelium and lamina propria of non-atopic patients (haematoxylin and eosin stain, magnification $400 x)$.

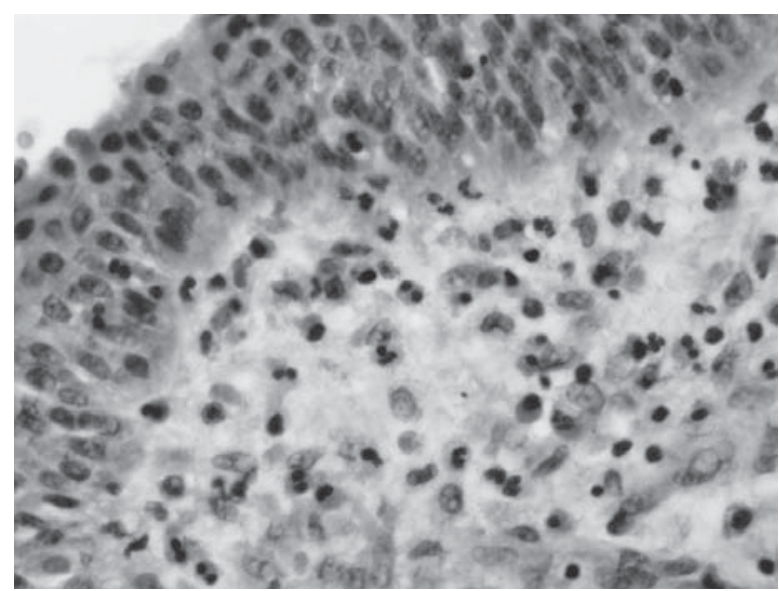

Figure 2 Strong eosinophil infiltration in the surface layer of nasal polyp epithelium of atopic patients (haematoxylin and eosin stain, magnification 400x).

with allergic rhinitis $(55.92 \pm 5.82$ vs. $16.83 \pm 7.89$, $\mathrm{p}<0.0001)$. A significant difference was also found between patients with allergic rhinitis and non-atopic patients $(16.83 \pm 7.89 v s .11 .12 \pm 2.03, \mathrm{p}=0.025)$ (Table $3)$.

Histology seems to confirm the above findings. Figures 1 and 2 show plenty of eosinophils in the samples taken from patients with allergic rhinitis and atopic nasal polyposis patients, while in non-atopic patients eosinophil infiltration was scarce (Figure 3).

We found no statistically significant correlation between IL-5 levels in nasal secretions and eosinophil counts. However, the correlation was positive between the ECP and eosinophil counts in non-atopic nasal polyposis patients and patients with allergic rhinitis (Table 4). 
Table 3 Eosinophil counts in nasal mucosa tissue samples

\begin{tabular}{lccc}
\hline & Allergic rhinitis & Non-atopic nasal polyposis & Atopic nasal polyposis \\
\hline $\begin{array}{l}\text { Number of } \\
\text { eosinophils }\end{array}$ & $16.83 \pm 7.89^{\mathrm{a}, \mathrm{b}}$ & $11.12 \pm 2.03^{\mathrm{c}}$ & $55.92 \pm 5.82$ \\
\hline
\end{tabular}

a difference from non-atopic nasal polyposis $p<0.025$

$b, c$ difference from atopic nasal polyposis $p<0.0001$

Table 4 Correlation between mediator levels in nasal secretions and eosinophil counts in nasal tissue samples

\begin{tabular}{lccc}
\hline \multirow{2}{*}{ Mediators } & \multicolumn{3}{c}{ Eosinophils } \\
\cline { 2 - 4 } & Allergic rhinitis & Non-atopic nasal polyposis & Atopic nasal polyposis \\
\hline IL-5 & NS & NS & NS \\
\hline \multirow{2}{*}{ ECP } & $R=0.932$ & $R=0.843$ & NS \\
& $p=0.01$ & $p=0.01$ & \\
\hline
\end{tabular}

NS: difference not significant

\section{DISCUSSION}

The prevalence of allergic rhinitis and asthma has been increasing in many countries around the world $(1,11)$. Studies vary in reporting the incidence of allergy in patients with nasal polyps. Several authors found little association between allergy and nasal polyps (18-20). In contrast, Bachert et al. (21) suggested an association between allergic reaction in the inflamed nasal mucosa and increased total and specific IgE in polyps, without systemic manifestation of allergy. Klossek et al. (22) found that allergy was significantly more frequent in the nasal polyp patient group than in the control group (27.1\% vs. $11.9 \%$, respectively). Asero et al. (23) found that $55 \%$ of nasal polyp patients had a positive skin prick test to at least one allergen. Jovićević and Kljajić (24) found that about $30 \%$ of patients with allergic rhinitis had nasal polyposis. Finally, Muñoz del Castillo et al. (25) demonstrated a positive skin prick test in $63.2 \%$ of 190 nasal polyp patients. However, the relationship between nasal polyposis and allergy remains unclear.

Our study has shown significantly higher IL-5 levels in the nasal secretions of patients with nasal polyposis and allergy than in non-atopic nasal polyposis patients. IL-5 seems to play an important role in the pathogenesis of allergic rhinitis and nasal polyposis, as activates and mobilises eosinophils, and stimulates differentiation and growth of B lymphocytes (26). Infiltration and activation of eosinophils are the hallmark of nasal polyp tissue $(4,26)$. Findings presented by Fan et al. (4) suggest that T-cell-secreted IL-5 and autosecretion of IL-5 from activated eosinophils may be the reasons for persistent and growing eosinophil inflammation in the nasal polyp tissue. Activated eosinophils release plenty of cytotoxic proteins and transforming growth factors that cause epithelial injury, basement membrane thickening, glandular hyperplasia, stromal fibrosis, and angiogenesis $(4,26)$. Saitoh et al. (27) found a significant correlation in eosinophilic infiltration between the epithelium and lamina propria. Therefore, it is likely that eosinophils migrating into the epithelium continue to secrete cytotoxic mediators and eventually directly add to the epithelial damage. Furthermore, the correlation between eosinophilic infiltration in the epithelium and epithelial damage was higher than that between eosinophilic infiltration of the lamina propria and epithelial damage, which suggests that epithelial eosinophils may contribute much more to an aggressive model of nasal polyposis (27).

Our study has shown higher levels of IL-5 and ECP in the nasal fluid of atopic patients with nasal polyposis than in patients with allergic rhinitis or non-atopic nasal polyposis. Eosinophil count was about three times as high as in atopic patient polyps as in the nasal mucosa of patients with allergic rhinitis, and about four times as high as in non-atopic patient polyps. This is in accordance with results presented by Cheng et al. (28).

We also found a positive correlation between the ECP levels in nasal fluid and eosinophil counts in all three groups of patients, but this correlation was not significant in the atopic nasal polyposis patients. While ECP is toxic to pathogens, helminth in particular, it can also damage airway epithelial cells, elicit local oedema, and produce airway hyperreactivity in asthma and allergic rhinitis patients (29). It is used as a 
standard marker of eosinophil activity and is strongly involved in upper and lower airway inflammation, such as chronic rhinitis/rhinosinusitis and bronchial asthma (30). Rasp et al. (31) found that ECP levels were significantly higher in nasal secretions than in the serum and are better connected to disease activity and prefer ECP determination in nasal fluid over serum to assess the severity of upper airway inflammation (31). Sun et al. (32) demonstrated that ECP levels in the nasal fluid of patients with nasal polyposis correlated with asthma and aspirin intolerance.

To conclude, allergic nasal polyposis patients in our study showed a higher level of eosinophilic inflammation than non-allergic patients with nasal polyps or patients with allergic rhinitis. ECP levels in nasal fluid correlated well with the number of eosinophils and could be useful in evaluating the degree of inflammation in patients with allergic rhinitis and in patients with nasal polyposis.

\section{REFERENCES}

1. Van Hoecke H, van Cauwenberge P, Thas O, Watelet JB. The ARIA guidlines in specialist practice: a nationwide survey. Rhinology 2010;48:28-34.

2. Skitarelić N, Mazzi A, Skitarelić I, Mišulić B, Vuletić A. Učestalost senzibilizacije na pelud masline u bolesnika $\mathrm{s}$ peludnom alergijom na području Zadra [Hypersensitivity to pollen of Olea europea in patients with pollen allergy in Zadar country, Croatia, in Croatian]. Arh Hig Rada Toksikol 2010;61:211-7.

3. Kramer MF, Ostertag P, Pfrogner E, Rasp G. Nasal interleukin-5, immunoglobulin $\mathrm{E}$, eosinophilic cationic protein, and soluble intercellular adhesion molecule-1 in chronic sinusitis, allergic rhinitis, and nasal polyposis. Laryngoscope 2000;110:1056-62.

4. Fan GK, Wang H, Takenaka H. Eosinophil infiltration and activation in nasal polyposis. Acta Otolaryngol 2007;127:5216.

5. Rostkowska-Nadolska B, Pazdro-Zastawny, Ziółkowski P, Gamian E, Jaworska M, Bochnia M, Jabłonka A. Expression of basic fibroblast growth factor in nasal polyps. Adv Clin Exp Med 2008;17:33-40.

6. Veyseller B, Aksoy E, Ertaş B, Keskin M, Ozturan O, Yildirim YS, Bayraktar EG, Oztürk H. A new oxidative stress marker in patients with nasal polyposis: advanced oxidation protein product (AOPP). B-ENT 2010;6:105-9.

7. Bonfils P, Avan P, Malinvaud D. Influence of allergy on the symptoms and treatment of nasal polyposis. Acta Otolaryngol 2006;126:839-44.

8. Ramanathan M, Lee WK, Spannhake EW, Lane AP. Th2 cytokines associated with chronic rhinosinusitis with polyps down-regulate the antimicrobial immune function of human sinonasal epithelial cells. Am J Rhinol 2008;22:115-21.

9. Jankowski R, Persoons M, Foliguet B, Coffinet L, Thomas C, Verient-Montaut B. Eosinophil count in nasal secretions of subjects with and without nasal symptoms. Rhinology 2000;38:23-32.

10. Fokkens W, Lund V, Mullol J; European Position Paper on Rhinosinusitis and Nasal Polyps group. European posistion paper on rhinosinusitis and nasal polyps 2007. Rhinol 2007;45(Suppl 20):1-136.

11. Bachert C, Jorissen M, Bertrand B, Khaltaev N, Bousquet J. Allergic rhinitis and its impact on asthma update (ARIA 2008). The Belgian perspective. B-ENT 2008;4:253-7.

12. Alatas N, Baba F, San I, Kurcer Z. Nasal polyp diseases in allergic and nonallergic patients and steroid therapy. Otolaryngol Head Neck Surg 2006;135:236-42.

13. Elmorsy S, El-Naggar MM, Abdel aal SM, Abou-elela MA. Sinus aspirates in chronic rhinosinusitis: fungal colonization of paranazal sinuses, evaluation of ICAM- 1 and IL- 8 and studying of immunological effect of long-term macrolide therapy. Rhinology 2010;48:312-7.

14. Watelet JB, Gevaert P, Holtappels G, van Cauwenberge P, Bachert C. Collection of nasal secretions for immunological analysis. Eur Arch Otorhinolaryngol 2004;261:242-6.

15. Perić A, Vojvodić D, Radulović V, Vukomanović-Đurđević $\mathrm{B}$, Miljanović O. Correlation between cytokine levels in nasal fluid and eosinophil counts in nasal polyp tissue in asthmatic and nonasthmatic patients. Allergol Immunopathol (Madr) 2011;39:133-9.

16. Perić A, Vojvodić D, Radulović V, Vukomanović-Đurđević B, Perić AV, Miljanović O. Proinflammatory cytokine levels in nasal fluid as indicators of severity of nasal polyposis. Acta Clin Croat 2010;49:395-403.

17. Perić A, Vojvodić D, Vukomanović-Đurđević B. Nasal polyps with more intense epithelial eosinophil infiltration respond worse to long-term low-dose treatment by clarithromycin. Adv Clin Exp Med 2011;20:325-34.

18. Settipane GA, Klein DE, Settipane RJ. Nasal polyps. State of the art. Rhinology 1991;Suppl 11:33-6.

19. Caplin I, Hynes TJ, Spahn J. Are nasal polyps an allergic phenomenon? Ann Allergy 1971;29:631-4.

20. Mygind N, Dahl R, Bachert C. Nasal polyposis, eosinophil dominated inflammation and allergy. Thorax 2000;55(Suppl 2):S79-83

21. Bachert C, Gevaert P, Holtappels G, Johansson SGO, Van Cauwenberge P. Total and specific IgE in nasal polyps is related to local eosinophilic inflammation. J Allergy Clin Immunol 2001;107:607-14.

22. Klossek JM, Neukirch F, Pribil C, Jankowski R, Serrano E, Chanal I, El Hasnaoui A. Prevalence of nasal polposis in France: a cross-sectional, case-control study. Allergy 2005;60:233-7.

23. Asero R, Bottazi G. Hypersensitivity to molds in patients with nasal polyposis: A clinical study. J Allergy Clin Immunol 2000;105:186-8.

24. Jovićević J, Kljajić V. [Nasal polyposis and allergic rhinitisour experience, in Serbian]. SrpArh Celok Lek 2005;133(Suppl 2):105-7.

25. Muñoz del Castillo F, Jurado-Ramos A, Fernandez-Conde BL, Soler R, Barasona MJ, Cantillo E, Moreno C, Guerra F. Allergenic profile of nasal polyposis. J Investig Allergol Clin Immunol 2009;19:110-16.

26. Bachert C, Wagenmann M, Rudack C, Höpken K, Hillebrandt $\mathrm{M}$, Wang D, van Cauwenberge P. The role of cytokines in infectious sinusitis and nasal polyposis. Allergy 1998;53:213. 
27. Saitoh T, Kusunoki T, Yao T, Kawano K, Kojima Y, Miyahara K, Onoda J, Yokoi H, Ikeda K. Relationship between epithelial damage or basement membrane thickness and eosinophilic infiltration in nasal polyps with chronic rhinosinusitis. Rhinology 2009;47:275-9.

28. Cheng W, Zheng C, Tian J, Shi G. T helper cell population and eosinophilia in nasal polyps. J Investig Allergol Clin Immunol 2007; 17:297-301.

29. Tiñana A, Borish L, Steinke J. Eosinophil. In: Önerci TM, Ferguson BJ, editors. Nasal polyposis: pathogenesis, medical and surgical treatment. Berlin-Heidelberg: Springer-Verlag; 2010. p. 35-44.
30. Zurak K, Bukovec Ž, Anzić SA, Baudoin T, Kalogjera L. Impact of inflammatory cell activation on nasal hyperreactive response to distilled water nasal provocation. Acta Clin Croat 2007;46:151-6.

31. Rasp G, Thomas PA, Bujia J. Eosinophil inflammation of the nasal mucosa in allergic and non-allergic rhinitis measured by eosinophil cationic protein levels in native nasal fluid and serum. Clin Exp Allergy 1994;24:1151-6.

32. Sun DI, Joo YH, Auo HJ, Kang JM. Clinical significance of eosinophilic cationic protein levels in nasal secretions of patients with nasal polyposis. Eur Arch Otorhinolaryngol 2009;266:981-6. 


\section{Sažetak}

\section{EOZINOFILNA UPALA U ALERGIJSKOM RINITISU I NOSNOJ POLIPOZI}

Na histopatološkim pregledima nosni polipi, kao i nosna sluznica u alergijskom rinitisu pokazuju različite oblike pseudoslojevitog respiracijskog epitela, dok je osnovna karakteristika lamine proprije infiltracija eozinofilima. Cilj ove studije bio je usporediti koncentracije interleukina 5 (IL-5) i eozinofilnoga kationskog proteina (ECP) u nosnome sekretu pacijenata s alergijskim rinitisom, neatopičnih i atopičnih pacijenata s nosnom polipozom, kao i usporediti broj eozinofila u tkivu nosnih polipa/nosne sluznice ovih pacijenata. Četrdeset dvoje $(n=42)$ pacijenata, 12-ero s alergijskim rinitisom i devijacijom nosnog septuma, 17-ero neatopičnih pacijenata s nosnom polipozom i 13-ero atopičnih pacijenata s nosnom polipozom bilo je uključeno u ovu presječnu studiju. Uzorci nosnog sekreta bili su skupljeni iz nosnih šupljina svih ispitanika nekoliko dana prije kirurškog liječenja. Koncentracije IL-5 mjerene su metodom protočne citometrije, dok su koncentracije ECP mjerene komercijalnim ELISA-kitom. Eozinofili su brojeni u svim uzorcima tkiva nosnih polipa, kao i u svim uzorcima tkiva sluznice uzetih s donje nosne školjke tijekom septoplastike. Značajno više koncentracije IL-5 izmjerene su u nosnom sekretu atopičnih pacijenata s nosnom polipozom u usporedbi s neatopičnim pacijentima s nosnom polipozom $(\mathrm{p}=0,025)$ i pacijentima s alergijskim rinitisom $(p=0,05)$. Naši su rezultati pokazali više koncentracije ECP u atopičnih pacijenata s nosnom polipozom nego u pacijenata s alergijskim rinitisom $(\mathrm{p}<0,0001)$ i u usporedbi s nealergičnim pacijentima s nosnom polipozom $(\mathrm{p}<0,0001)$. Veći broj eozinofila izbrojen je $\mathrm{u}$ tkivu polipa atopičnih pacijenata nego u tkivu polipa neatopičnih pacijenata ( $\mathrm{p}<0,0001)$, kao i u sluznici pacijenata s alergijskim rinitisom $(\mathrm{p}<0,0001)$. U nosnoj sluznici pacijenata s alergijskim rinitisom našli smo značajno veći broj eozinofila nego u polipima neatopičnih pacijenata s nosnim polipima $(\mathrm{p}=0,025)$. Konačno, našli smo pozitivnu korelaciju između nivoa ECP u nosnom sekretu i broja eozinofila u uzorcima tkiva u sve tri skupine ispitanika. Zaključili smo da atopični pacijenti s nosnom polipozom imaju viši stupanj eozinofilne upale u usporedbi s neatopičnim pacijentima s nosnim polipima i s pacijentima s alergijskim rinitisom.

KLJUČNE RIJEČI: eozinofili, eozinofilni kationski protein, epitel, interleukin 5, nosni sekret

\section{CORRESPONDING AUTHOR:}

Aleksandar Perić, MD, DSc

Department of Otorhinolaryngology, Rhinology Unit

Military Medical Academy, Crnotravska 17, 11040,

Belgrade, Serbia

E-mail:alexneta@sezampro.rs 